its economic services the Centre will certify that the firm is economically sound and give the managing director the data on which to base his development plans (supplies and outlets, market research, etc.). It studies problems of specialization, conversion and decentralization so that the firm may achieve optimum production conditions. It helps to set up common services and new organs of expansion (sub. contracting exchanges, export groups, market research services in France and abroad). The Centre will work in close liaison with trade associations, Government agencies, productivity centres, and banking credit establishments (European Productivity, 39; Autumn 1961).

\section{Research in the British Wool Textile Industry}

IN moving the approval of the Wool Textile Industry (Scientific Research Levy (Amendment) Order) in the House of Commons on January 23, the Parliamentary Secretary to tho Board of Trade, $\mathrm{Mr}$. N. Macpherson, explained that the purpose of the Order, made under the Industrial Organization and Development Act, 1947, was to increase by one-third the ratos of the levy payable by the wool textile industry for scientific research. The levy had yielded an average of $£ 184,000$ a year, most of which went to the Wool Industries Research Association, which also received a grant from the Department of Scientific and Industrial Research, and it was the policy of that Department that industry should carry a gradually increasing percentage cost of research. Work was also carried out for the Wool Textile Research Council by universities and technical colleges und it was considered likely that reserves held by the Board of Trade for the Research Council would be encroached on before the levy at the increased rate could be collected. The increase in the lovy had been roquested by the largest organization of employers in the industry and was warmly supported by the trade unions. Under the levy the maximum grant of $£ 70,000$, payable on an industrial contribution of $£ 170.000$, would rise to $£ 83,500$ on an industrial contribution of $£ 208,000$.

The Order, which was agreed, found general support in the H.ouse, but some comparisons were made between expenditure on research and development in the wool textile industry, which Mr. D. Ginsberg, and also Mr. H. Rhodes, put at about $£ 335,000$ a yoar, compared with $£ 3.3$ million a year by the manmade fibres industry, and he thought that entry into the Common Market would make the need for expenditure on research even more vital. Further, Mr. Rhodes quoted exponditure of $£ 4,451,000$ on research by the rayon industry, only 7 per cent of which was conducted by the research association compared with 84 per cont in the wool and worsted trades. Tributes were freely pair to the work of the Wool Industries Research Association, but both Mr. Rhodes and Mr. G. R. Mitchison also referred to the importance of the wise selection of projeets and to the need for effective co-operation between different research associations. Mr. Mitchison, in particular, questioned whether either the President of the Board of Trade or the Minister for Science was able to ensure effective co-ordination, and thought that the Minister for Science should be responsible for stimulating the application of new scientifie and technical knowlodgo in small firms. Mr. Macphorson in his reply suggosted that the availability of information was primarily a matter for the Research Association itself.

\section{Metallurgy of Steel}

A Physical Metallurgy Section has been set up in the British Iron and Steel Research Association's Metallurgy Division to apply the latest metallographic techniques to the study of the behaviour and properties of steels. Mr. R. Phillips, formerly of the Aeon Laboratories, has been appointed head of the Section, which is equipped with the Siemens Elmiskop I $100 \mathrm{kV}$. electron microscope, and the basic A.E.I. micro-probe analyser complete with scanning attachment, together with a wide range of optical metallographic equipment. The prime purpose of the Section will be to carry out its own research programme on the development of improved steels, but its facilities will be available to member companies who require metallographic studies to be made.

\section{International Commission on Zoological Nomen- clature}

Notice is given of the possible use by the Inter. national Commission on Zoological Nomenclature of its plenary powers in connexion with the following cases, full details of which can be found in the Bulletin of Zoological Nomenclature, 19, Part 1, published on February 2, 1962: (1) validation of Scolytus Geoffroy, 1762 (Insecta, Coleoptera). Z.N.(S.) 81 ; (2) suppression of eight dubious specific names of birds. Z.N.(S.) 1033); (3) designation of a type-species for Ammodiscus Reuss, 1862 (Foraminifera). Z.N.(S.) 1087; (4) validation of two species named Ammonites laevigata by J. de C. Sowerby, 1827 (Cephalopoda). Z.N.(S.) 1203 ; (5) validation of Biomphalaria Preston, 1910 (Gastropoda). Z.N.(S.) 1392; (6) preservation of Argyrodes Simon, Dipoenura Simon, Robertus O. Pickard-Cambridge, and Theonoe Simon (Araneae). Z.N.(S) 1481 ; (7) validation of Corixa affinis Leach, 1817 (Insecta, Hemiptera). Z.N.(S.) 1482; (8) designation of a type-species for Dromia Weber, 1795 (Crustacea, Decapoda). Z.N.(S.) 1488; (9) validation of Parthenope Fabricius, 1798, and Lambrus Leach, 1815 (Crustacea, Decapoda). Z.N.(S.) 1487; (10) validation of Corystes Latreille [18021803] (Crustacea, Decapoda). Z.N.(S.) 1486. Any zoologist who wishes to comment on any of the above cases should do so in writing, and in duplicate, as soon as possible, and in any case before August 2, 1962. Each comment should bear the reference number of the case in question. Comment received early enough will be published in the Bulletin of Zoological Nomenclature. Those received too late for publication will, if received before August 2, 1962, be brought to the attention of the Commission at the timo of commencement of voting. All com. munications on the above subject should be addressed to the Secretary, International Commission on Zoological Nomenclature, c/o British Museum (Natural History), Cromwell Road, London, S.W.7.

\section{NATO Lectures on Tides and Storm Surges}

A course of North Atlantic Treaty Organization lectures entitled "Tides and Storm Surges", arranged by the Tidal Institute and Observatory, University of Liverpool, is to be held in tho University during March 26-30. The lectures to be delivered will include: gravity waves-theory and hypothesis (Dr. B. Saint-Guily, Paris); the nature of the problem in oceans and seas (Prof. W. Hansen, Hamburg); the nature of the problem in coastal waters and estuaries (Dr. J. R. Rossiter, Liverpool); the analytical problem-recent developments in the analytical treatment 